\title{
Diagnosis of Respiratory Syncytial Virus Infection
}

\author{
Therese Popow-Kraupp ${ }^{1,2, *}$ and Judith H. Aberle ${ }^{1}$
}

${ }^{I}$ Department of Virology, Medical University of Vienna, Austria

${ }^{2}$ Division of Clinical Virology, Department of Laboratory Medicine, Medical University of Vienna, Austria

\begin{abstract}
Respiratory syncytial virus (RSV) is one of the most important pathogen causing severe lower respiratory tract infections in all age groups often requiring hospitalization. Rapid laboratory diagnosis of RSV infection significantly decreases the use of antibiotics, additional laboratory testing and is associated with shorter hospitalization periods. The specific diagnosis of RSV infection is based on the detection of virus or viral antigens or virus specific nucleic acid sequences in respiratory secretions. The kind and quality of the clinical specimen exerts a considerable influence on the results of all currently used viral detection assays. Antigen based tests are widely available, easy to perform and the results are available in a short time but their reduced sensitivity and specificity represent a considerable shortcoming. Among the methods available isolation in cell culture was considered the gold standard for the sensitive identification of RSV but is gradually replaced by highly sensitive and specific nucleic acid amplification assays that provide more rapid results. Of these reverse transcription polymerase chain reaction (PCR) was the first and is still the most frequently used nucleic acidbased assay. New methodologies, as for example the real-time PCR methods allow the quantification of viral nucleic acids in the clinical sample. Disadvantages of the nucleic acid based assays are their high costs and their limited standardization.

Future research on new methodologies for the diagnosis of viral respiratory tract infections should focus on the development of sensitive, rapid and cost effective test systems allowing the screening for all probable causative agents. In addition varying testing protocols for summer and winter months based on epidemiologic data are needed to direct their practical use.
\end{abstract}

Keywords: Respiratory syncytial virus, sporadic, cardiopulmonary, immunofluorescent.

\section{INTRODUCTION}

Respiratory syncytial virus (RSV) is one of the most important respiratory pathogens, causing severe infections of the lower respiratory tract in infants, small children, the elderly, and in immunosuppressed patients, often requiring hospitalization [1-7]. RSV is highly contagious and gives rise to yearly epidemic outbreaks of respiratory tract infections during the late fall, winter and early spring with only sporadic cases detected year round [1, 8-10] (Fig. 1).

Almost all children have serologic evidence of RSV infection by 2 years of age. Primary RSV infection is rarely asymptomatic and the peak period of serious illness due to RSV is during the first few months of life with average annual hospitalization rates of 17 per 1000 children under 6 months of age and 3 per 1000 children under 5 years of age [12]. Underlying conditions, most frequently premature birth or cardiopulmonary disease are additional risk factors for severe RSV disease requiring hospitalization [13, 14]. In addition, previous RSV infections do not confer protection and reinfections throughout life are very common $[15,16]$. Despite an increasing number of newly identified respiratory

*Address correspondence to this author at the Department für Virologie, Medizinische Universität Wien, Kinderspitalgasse 15, A-1090 Wien, Klinische Abteilung für Virologie, Klinisches Institut für Labormedizin, Medizinische Universität Wien, Währinger Gürtel 18-20, A-1090 Wien, Austria; Tel: +43 1404 00-5149; Fax: +43 1404 00-5135;

E-mail: Theresia.Popow-Kraupp@meduniwien.ac.at viruses, RSV remains the most important etiologic agent in infants below two years of age hospitalized with acute respiratory tract infection (Fig. 2).

Due to the high number of potential pathogens that may cause similar symptoms of respiratory illness, clinical characteristics are rarely distinctive enough to accurately discriminate RSV-related from other, non-RSV-related respiratory tract infections [18, 19]. Laboratory confirmation of clinically suspected RSV infection generally depends on the detection of the virus in respiratory secretions of the patient. Immunofluorescent staining of viral antigens in respiratory epithelial cells, introduced by Philipp Gardner in the 1970ies $[20,21]$ was the first specific rapid diagnostic test. Since then rapid, sensitive and specific diagnostic tools have been developed and their increasing availability and use unveiled the prominent role of RSV in lower respiratory tract infection in childhood and the strong association of RSV bronchiolitis in infancy and wheezing in later childhood [22-24]. The following article will provide a short review on the diagnostic value, the advantages and limitations of the most currently used techniques for RSV diagnosis.

\section{Clinical Manifestations}

RSV infection is associated with a variety of clinical manifestations ranging from mild cold-like symptoms to severe lower respiratory tract illness with significant wheezing, breathing difficulty, cyanosis and possibly apnoeic epi- 


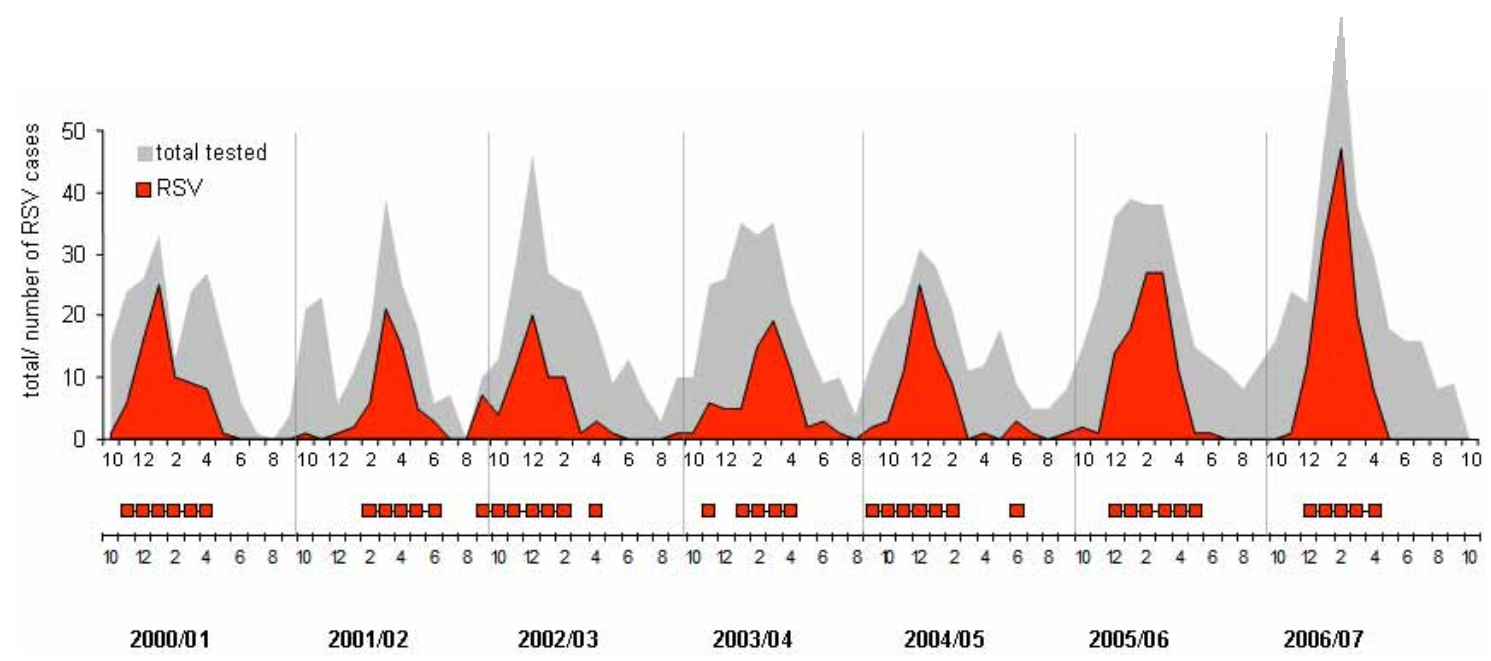

Fig. (1). Seasonality of respiratory syncytial virus (RSV) in Austria from 2000 to 2007 (top panel). The weeks of onset and offset of RSV activity (bottom panel) are defined as the first of two consecutive cases when $>10 \%$ of respiratory secretions test positive by PCR and the last week of $>10 \%$ positive tests preceding 2 consecutive weeks of $<10 \%$ positive tests, as described in the annual report NREVSS 2005 [11].

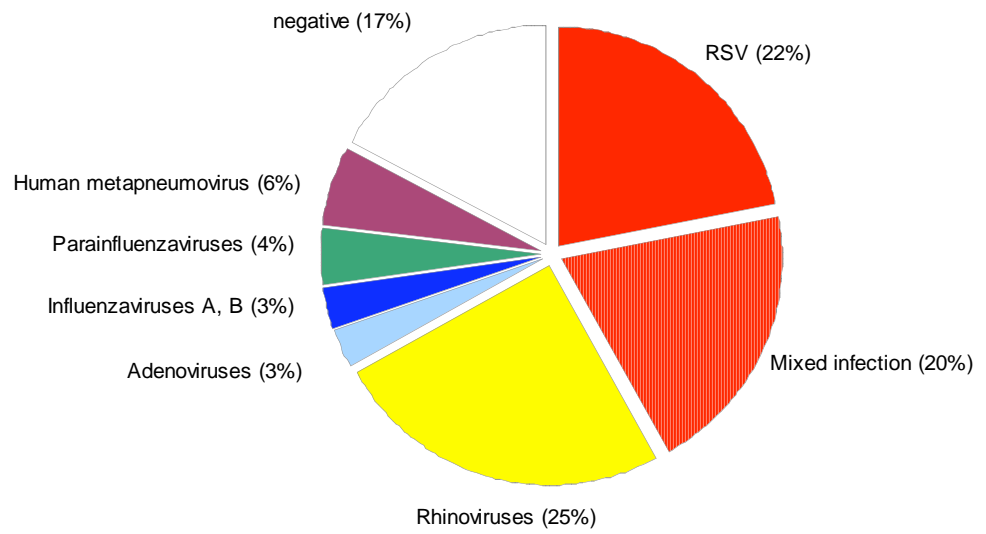

Fig. (2). Detection of respiratory viruses in NPAs obtained from 772 infants hospitalized with acute respiratory tract illness from October 2000 through July 2004 [17].

sodes. Between $25 \%$ and $40 \%$ of children develop symptoms of bronchiolitis or pneumonia during their primary RSV infection [25-28]. In addition to the more common symptoms of lower respiratory tract infection a variety of extrapulmonary manifestations, ranging from cardiac involvement to sepsis-like syndrome have been observed in children with severe RSV disease [29, 30], but whether they represent direct or indirect effects of the virus is unclear. In premature infants RSV infection is frequently atypical in its clinical presentation and may manifest as apnoea, bradycardia, or changes in feeding and ventilation $[13,31]$.

\section{Reasons for RSV Testing}

Rapid laboratory confirmation of RSV infection results in a reduced number of ancillary tests, a decrease in antibiotic use and shorter hospitalization periods in clinical paediatric practice [32, 33]. Laboratory diagnosis is also required for children with atypical clinical presentations, such as respiratory distress or sepsis like syndrome and in premature infants with non-specific signs in order to rule out another cause and to avoid delayed diagnosis. As RSV is highly contagious, rapid identification of RSV infected infants in hospital wards is of utmost importance in order to initiate appropriate infec- tion control precautions to prevent nosocomial outbreaks [4, $13,34]$. Viral testing using rapid and sensitive assays for the detection of RSV are also required to take the offensive for preventive programs and to assess the efficacy of antiviral prophylaxis [35, 36]. Other reasons for viral testing exist, such as for research and epidemiologic monitoring of RSV activity.

\section{Laboratory Diagnosis}

The specific diagnosis of RSV infection is made by the detection of the virus or viral antigens or virus specific nucleic acid sequences in respiratory secretions. The kind and quality of the clinical specimen exerts a considerable influence on the sensitivity and specificity of all viral detection assays currently available. It has been demonstrated that a nasal wash or a nasopharyngeal aspirate is more sensitive for the detection of RSV than a nasopharyngeal swab specimen $[37,38]$. However the collection of a nasopharyngeal swab is far less unpleasant for the patient, does not require specialized equipment, and can also be performed in an out-patient setting. Using the recently designed flocked-nasopharyngealswabs, which effectively dislodge and collect virus infected cells lining the nasopharynx greatly improves the quality of 
swab specimens and significantly increases the diagnostic yield of this clinical specimen [39-42].

Laboratory methods currently available for the detection of RSV include virus isolation in tissue culture, detection of viral antigens by direct or indirect immunofluorescent (IF) staining (DFA/IFA) or by enzyme-linked immunosorbent assays (EIAs) and the detection of viral nucleic acids by amplification assays, predominantly reverse transcription polymerase chain reaction (RT-PCR).

\section{Virus Isolation in Tissue Culture}

Isolation of RSV in tissue culture was considered as the gold standard for confirmation of presumed RSV infection for quite a long period of time. However besides the technical expertise in appropriate specimen handling for efficient virus recovery, this technique requires an average of 3 to 6 days until syncytial cytopathic effect appears. Shell vial centrifugation cultures followed by DFA or immunoperoxidase staining using virus specific monoclonal antibodies significantly increases the sensitivity of the tissue culture technique and shortens the turnaround time for virus identification to 1 to 2 days [43-45].

The advantage of the tissue culture technique is that it is more sensitive than rapid antigen detection kits and that it provides the ability of further antigenic and genetic characterization of the amplified virus which can be used for the screening of epidemiological relevant mutations or for the confirmation of nosocomial transmission by sequence analysis [46-48].

\section{Antigen Detection}

Antigen detection assays include direct immunofluorescence assays (DFA), enzyme immunosorbent assays (EIA), chromatographic and optical immunoassays [49-54]. The DFA uses fluorescein-labelled antibodies that detect RSV antigen in epithelial cells in respiratory secretions and has the advantage that the immunofluorescence pattern of the infected cells can be directly examined by microscopy which provides additional confirmation of specificity. In the EIA, RSV antigen, if present, is captured by RSV-specific antibodies and will be detected by a second enzyme-linked antibody. Antigen detection kits are easy to perform and the results are available in a short time. For these reasons they are widely used in clinical practice. Currently available antigen detection kits in paediatric specimens have sensitivities of 72 to $94 \%$ and specificities of 95 to $100 \%$ as compared to cell culture (Table 1). However, in older children and adults, detection rates for EIA are extremely low with sensitivities of 0 to $20 \%$ (Tables 1 and 2), most likely because of the substantially lower viral titre and shorter virus shedding in a group of patients experiencing RSV reinfections [55]. The

Table 1. Evaluation of RSV Rapid Antigen Detection Tests in Respiratory Specimens Obtained from Children and Adults with RSV Infection Confirmed by Cell Culture

\begin{tabular}{|l|c|c|c|c|c|c|c|c|}
\hline \multicolumn{1}{|c|}{ Assays } & \multicolumn{2}{c|}{ \% Sensitivity } & \multicolumn{2}{c|}{ \% Specificity } & \multicolumn{2}{c|}{ Positive Predictive Value } & \multicolumn{2}{c|}{ Negative Predictive Value } \\
\hline \hline & $\begin{array}{c}\text { Children } \\
\mathrm{n}=108\end{array}$ & $\begin{array}{c}\text { Adults } \\
\mathrm{n}=41\end{array}$ & $\begin{array}{c}\text { Children } \\
\mathrm{n}=127\end{array}$ & $\begin{array}{c}\text { Adults } \\
\mathrm{n}=53\end{array}$ & $\begin{array}{c}\text { Children } \\
\mathrm{n}=84\end{array}$ & $\begin{array}{c}\text { Adults } \\
\mathrm{n}=34\end{array}$ & $\begin{array}{c}\text { Children } \\
\mathrm{n}=66\end{array}$ & $\begin{array}{c}\text { Adults } \\
\mathrm{n}=22\end{array}$ \\
\hline DFA & 93 & 100 & 97 & 97 & 95 & 80 & 96 & 91 \\
\hline BD Directigen & 81 & 25 & 95 & 98 & 90 & 50 & 90 & 82 \\
\hline BD Directigen EZ & 72 & 0 & 98 & 100 & 93 & & 96 & 94 \\
\hline Binax Now & 94 & 0 & 100 & 100 & 100 & & 96 \\
\hline
\end{tabular}

DFA, direct immunofluorescence assay (Merifluor RSV identification reagent, Meridian Bioscience Inc., Cincinnati, Ohio); BD Directigen, direct enzyme immunoassay and BD Directigen EZ (Becton Dickinson, Cockeysville, MD); Binax Now, rapid immunoassay (Binax, Inc., Portland, Maine), modified from [50].

Table 2. Evaluation of RSV Rapid Antigen Detection Tests in Respiratory Specimens Obtained from Adults with RSV Infection Confirmed by Cell Culture and/or Serology and/or RT-PCR

\begin{tabular}{|l|c|c|c|c|c|}
\hline \multicolumn{1}{|c|}{ Assays } & $\begin{array}{c}\text { n Positive out of 60 } \\
\text { Confirmed Infections }\end{array}$ & \% Sensitivity & \% Specificity & $\begin{array}{c}\text { Positive Predictive } \\
\text { Value }\end{array}$ & $\begin{array}{c}\text { Negative Predictive } \\
\text { Value }\end{array}$ \\
\hline \hline Cell culture & 28 & 46 & 100 & 100 & 95 \\
\hline RT-PCR & 49 & 82 & 100 & 40 & 98 \\
\hline DFA & 14 & 23 & 97 & 40 & 92 \\
\hline VIDAS & 12 & 20 & 97 & 25 & 92 \\
\hline BD Directigen & 6 & 10 & 97 & \\
\hline
\end{tabular}

DFA, direct immunofluorescence assay (Bartels (Bartels, Inc., Issaquah, WA); VIDAS, automated enzyme immunoassay (BioMerieux, Inc., Hazelwood, MI); Directigen, direct enzyme immunoassay (Becton Dickinson, Cockeysville, MD), modified from [58]. 
specificity of antigen detection kits may be significantly reduced, especially if used outside the epidemic periods, when the prevalence of the virus in the community is low and the rate of false positive results becomes relatively high [56-60]. Although numerous efforts are undertaken to improve the sensitivity and specificity of antigen detection kits, methods are less specific and far less sensitive than nucleic acid amplification assays [61-63].

\section{Nucleic Acid Tests (NATs)}

Nucleic acid assays have revolutionized the diagnostic procedures in virology and are the most sensitive and specific methods for the detection of RSV, regardless of the patient population tested [58, 64-69]. Studies comparing molecular diagnostic assays to virus isolation in cell culture and to antigen detection assays have demonstrated superior sensitivity for nucleic acid tests [62, 63, 70-73] (Table 2) which leads to an approximately twofold increase of detection rates in infants with respiratory illness [71, 74]. Young children experiencing primary infection usually shed large quantities of RSV over a prolonged period of time. With the increasing number of subsequent infections, virus is shed in lower quantities for shorter times [75] due to the presence of secretory and humoral virus-specific antibodies influencing the degree of viral replication [76]. Therefore a decrease in the efficacy of RSV detection with increasing age of the patient has been reported in various studies [50, 56, 57, 70, 77-79]. Nevertheless molecular diagnostic assays are definitely also more sensitive for older age groups as a result of the lower virus production in these patients (Table 2, Fig. 3).

Of the different nucleic acid amplification techniques, reverse transcription polymerase chain reaction (RT-PCR) was the first and most frequently used nucleic acid-based assay [80-82]. In the last ten years, numerous in-house PCR protocols have been published for amplifying various gene segments of the RSV genome [70, 83-87] and, in addition, an increasing number of commercial RSV NAT kits are now available.

New PCR techniques, as for example the real-time PCR methods, have been developed. Real-time PCR assays that use fluorescent probes such as Taqman, molecular beacons and scorpion probes enable the simultaneous performance of amplification and detection and result in a considerable increase in the speed of RT-PCR with a turnaround time of a few hours. Protocols have also been designed for simultaneous amplification of RSV together with various other respiratory viruses which cause similar clinical symptoms. These multiplex PCR assays are able to identify a variety of different respiratory viruses simultaneously, either within a single tube or by parallel detection in a single PCR run. Using highly sensitive monoplex or multiplex PCR assays, it turned out that a significant proportion of up to $10-30 \%$ of respiratory illness cases and up to $50 \%$ of RSV-infections in infants represent mixed infections of 2 or more respiratory viruses [17, 24, 74, 88-90] (Fig. 2). The impact of a coinfection on the clinical course of illness still remains controversial. A significantly increased risk of more severe disease or of admission to a paediatric intensive care unit has been reported for dual as compared to single respiratory virus detection by some [91-93], but not by other studies [17, 74].

An important benefit of real-time PCR is that it allows quantification of viral nucleic acids present in a sample [66, 77]. The diagnostic value of the determination of viral loads in respiratory tract infections is still unclear, because respiratory specimens are difficult to standardize, especially with regard to the amount of virus or virus-infected cells within specimens and the non-standardized dilution of samples.

As far as RSV is concerned higher viral loads seem to correspond with a more severe clinical course of the disease $[94,95]$ and an increased likelihood of recurrence of wheezing [24]. In patients in whom multiple viruses are detected quantitative RT-PCR may help to discriminate between the virus actually causing the acute respiratory disease and those simultaneously detected but without a causative relationship to the actual clinical symptoms.

\section{Determination of RSV-Specific Antibodies (Serology)}

Testing for virus specific antibodies is not useful for the diagnosis of acute RSV-infection. A serologic response is usually not detectable in infants, despite severe RSV infec-

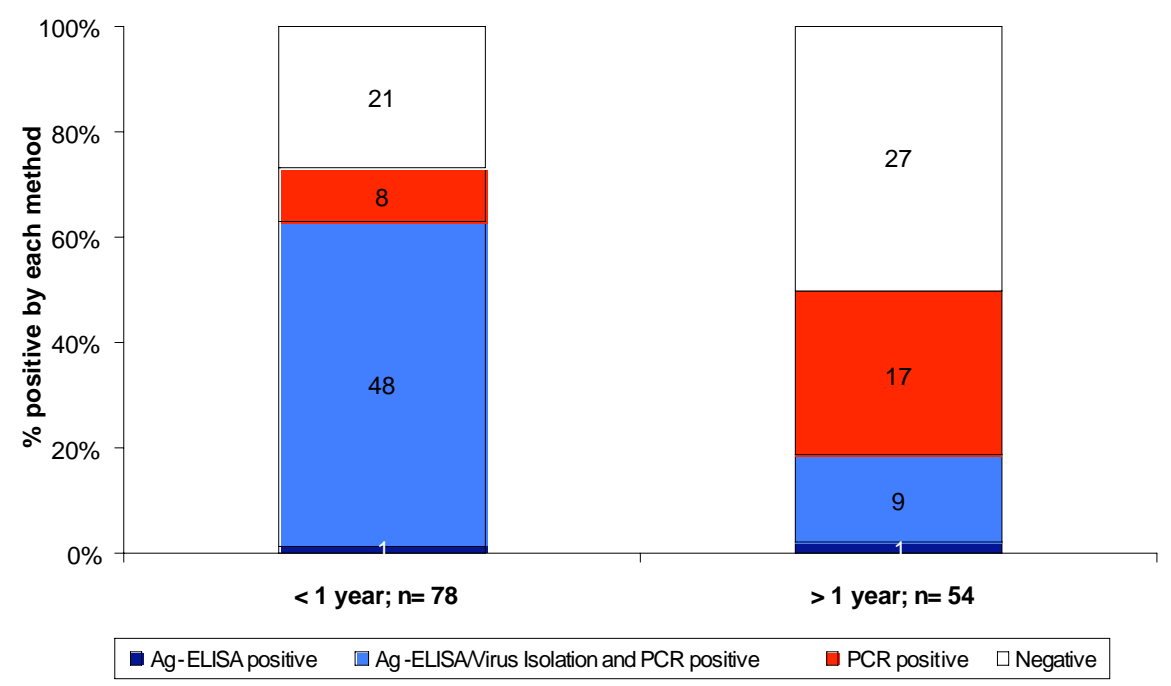

Fig. (3). Detection of Respiratory Syncytial Virus in NPAs by semi-nested RT-PCR, Ag-ELISA and Virus isolation with regard to the patient's age [70]. 
tion $[75,96]$. Even when sophisticated tests for the detection of class specific antibodies are used, the infant's own antibody response is barely detectable in the presence of maternally derived antibodies [97] and even in older children and groups of patients repeated infections are usually not associated with a detectable antibody response [75, 98]. Screening for RSV-specific antibodies is mostly performed to obtain seroepidemiologic information and for research purposes [99].

\section{FUTURE TRENDS AND NEEDS FOR IMPROVE- MENT}

Future developments for the diagnosis of viral respiratory tract infection should enhance the development of cost effective, sensitive and rapid tests allowing the screening of at risk populations for all probable causative agents. RTmultiplex PCRs have been developed to use numerous primers within a single reaction tube to amplify nucleic acid fragments from different respiratory viral pathogens. Up to now data on the comparative analysis between multiplex reactions and mono-reactions on the same sample indicate a reduced sensitivity and specificity of the multiplex systems [80]. Therefore more research is needed to overcome the problems associated with the use of multiple sets of high concentration primers and to identify reaction conditions that can be combined in order to obtain maximal specificity with a minimal loss in sensitivity. Target-enriched multiplexing amplification and the use of padlock probe design may aid to overcome these technical problems [100]. In addition optimized extraction procedures, improved standardisation associated with more automation and different testing protocols for summer and winter months based on epidemiologic data will provide accurate and clinically meaningful results that will considerably improve diagnosis of respiratory infections and directly impact patient management.

\section{REFERENCES}

[1] Kim HW, Arrobio JO, Brandt CD, et al. Epidemiology of respiratory syncytial virus infection in Washington, D.C. I. Importance of the virus in different respiratory tract disease syndromes and temporal distribution of infection. Am J Epidemiol 1973; 98: 216-25.

[2] Hall CB, Powell KR, MacDonald NE, et al. Respiratory syncytial viral infection in children with compromised immune function. $\mathrm{N}$ Engl J Med 1986; 315: 77-81.

[3] Agius G, Dindinaud G, Biggar RJ, et al. An epidemic of respiratory syncytial virus in elderly people: clinical and serological findings. J Med Virol 1990; 30: 117-27.

[4] Falsey AR, Treanor JJ, Betts RF, Walsh EE. Viral respiratory infections in the institutionalized elderly: clinical and epidemiologic findings. J Am Geriatr Soc 1992; 40: 115-9.

[5] Fleming DM, Cross KW. Respiratory syncytial virus or influenza? Lancet 1993; 342: 1507-10.

[6] Whimbey E, Couch RB, Englund JA, et al. Respiratory syncytial virus pneumonia in hospitalized adult patients with leukemia. Clin Infect Dis 1995; 21: 376-9.

[7] Welliver RC. Respiratory syncytial virus and other respiratory viruses. Pediatr Infect Dis J 2003; 22(2 Suppl): S6-10; discussion S10-2.

[8] Glezen P, Denny FW. Epidemiology of acute lower respiratory disease in children. N Engl J Med 1973; 288: 498-505.

[9] Parrott RH, Kim HW, Arrobio JO, et al. Epidemiology of respiratory syncytial virus infection in Washington, D.C. II. Infection and disease with respect to age, immunologic status, race and sex. Am J Epidemiol 1973; 98: 289-300.

[10] Gardner PS. How etiologic, pathologic, and clinical diagnoses can be made in a correlated fashion. Pediatr Res 1977; 11: 254-61.
[11] Brief report: respiratory syncytial virus activity--United States, 2005-2006. MMWR Morb Mortal Wkly Rep 2006; 55: 1277-9.

[12] Hall CB, Weinberg GA, Iwane MK, et al. The burden of respiratory syncytial virus infection in young children. N Engl J Med 2009; 360: 588-98.

[13] Hall CB. Nosocomial respiratory syncytial virus infections: the "Cold War" has not ended. Clin Infect Dis 2000; 31: 590-6.

[14] Welliver RC. Review of epidemiology and clinical risk factors for severe respiratory syncytial virus (RSV) infection. J Pediatr 2003; 143: S112-7.

[15] Henderson FW, Collier AM, Clyde WA, Jr, Denny FW. Respiratory-syncytial-virus infections, reinfections and immunity. A prospective, longitudinal study in young children. N Engl J Med 1979; 300: 530-4.

[16] McIntosh K. Respiratory syncytial virus--successful immunoprophylaxis at last. N Engl J Med 1993; 329: 1572-4.

[17] Aberle JH, Aberle SW, Pracher E, Hutter HP, Kundi M, PopowKraupp T. Single versus dual respiratory virus infections in hospitalized infants: impact on clinical course of disease and interferongamma response. Pediatr Infect Dis J 2005; 24: 605-10.

[18] Peltola V, Reunanen T, Ziegler T, Silvennoinen H, Heikkinen T. Accuracy of clinical diagnosis of influenza in outpatient children. Clin Infect Dis 2005; 41: 1198-200.

[19] Tregoning JS, Schwarze J. Respiratory viral infections in infants: causes, clinical symptoms, virology, and immunology. Clin Microbiol Rev; 23: 74-98.

[20] Gardner PS. Rapid diagnostic techniques in clinical virology. Mod Trends Med Virol 1970; 2: 15-50.

[21] Gardner PS. Respiratory syncytial virus infections. Postgrad Med J 1973; 49: 788-91.

[22] Stein RT, Sherrill D, Morgan WJ, et al. Respiratory syncytial virus in early life and risk of wheeze and allergy by age 13 years. Lancet 1999; 354: 541-5.

[23] Sigurs N, Gustafsson PM, Bjarnason R, et al. Severe respiratory syncytial virus bronchiolitis in infancy and asthma and allergy at age 13. Am J Respir Crit Care Med 2005; 171: 137-41.

[24] Bosis S, Esposito S, Niesters HG, et al. Role of respiratory pathogens in infants hospitalized for a first episode of wheezing and their impact on recurrences. Clin Microbiol Infect 2008; 14: 677-84.

[25] Glezen WP, Taber LH, Frank AL, Kasel JA. Risk of primary infection and reinfection with respiratory syncytial virus. Am J Dis Child 1986; 140: 543-6.

[26] McIntosh K. Pathogenesis of severe acute respiratory infections in the developing world: respiratory syncytial virus and parainfluenza viruses. Rev Infect Dis 1991; 13(Suppl 6): S492-500.

[27] Hall CB. Respiratory syncytial virus and parainfluenza virus. $\mathrm{N}$ Engl J Med 2001; 344: 1917-28.

[28] Checchia P. Identification and management of severe respiratory syncytial virus. Am J Health Syst Pharm 2008; 65: S7-12.

[29] Checchia PA, Appel HJ, Kahn S, et al. Myocardial injury in children with respiratory syncytial virus infection. Pediatr Crit Care Med 2000; 1: 146-50.

[30] Eisenhut M. Extrapulmonary manifestations of severe respiratory syncytial virus infection--a systematic review. Crit Care 2006; 10: R107.

[31] Woo PC, Chiu SS, Seto WH, Peiris M. Cost-effectiveness of rapid diagnosis of viral respiratory tract infections in pediatric patients. J Clin Microbiol 1997; 35: 1579-81.

[32] Barenfanger J, Drake C, Leon N, Mueller T, Troutt T. Clinical and financial benefits of rapid detection of respiratory viruses: an outcomes study. J Clin Microbiol 2000; 38: 2824-8.

[33] Byington CL, Castillo H, Gerber K, et al. The effect of rapid respiratory viral diagnostic testing on antibiotic use in a children's hospital. Arch Pediatr Adolesc Med 2002; 156: 1230-4.

[34] Falsey AR, McCann RM, Hall WJ, et al. Acute respiratory tract infection in daycare centers for older persons. J Am Geriatr Soc 1995; 43: 30-6.

[35] Willwerth BM, Harper MB, Greenes DS. Identifying hospitalized infants who have bronchiolitis and are at high risk for apnea. Ann Emerg Med 2006; 48: 441-7.

[36] Ralston S, Hill V. Incidence of apnea in infants hospitalized with respiratory syncytial virus bronchiolitis: a systematic review. J Pediatr 2009; 155: 728-33.

[37] Heikkinen T, Marttila J, Salmi AA, Ruuskanen O. Nasal swab versus nasopharyngeal aspirate for isolation of respiratory viruses. J Clin Microbiol 2002; 40: 4337-9. 
[38] Lambert SB, Whiley DM, O'Neill NT, et al. Comparing nose-throat swabs and nasopharyngeal aspirates collected from children with symptoms for respiratory virus identification using real-time polymerase chain reaction. Pediatrics 2008; 122: e615-20.

[39] Abu-Diab A, Azzeh M, Ghneim R, et al. Comparison between pernasal flocked swabs and nasopharyngeal aspirates for detection of common respiratory viruses in samples from children. J Clin Microbiol 2008; 46: 2414-7.

[40] Moore C, Corden S, Sinha J, Jones R. Dry cotton or flocked respiratory swabs as a simple collection technique for the molecular detection of respiratory viruses using real-time NASBA. J Virol Methods 2008; 153: 84-9.

[41] Walsh P, Overmyer CL, Pham K, et al. Comparison of respiratory virus detection rates for infants and toddlers by use of flocked swabs, saline aspirates, and saline aspirates mixed in universal transport medium for room temperature storage and shipping. $\mathbf{J}$ Clin Microbiol 2008; 46: 2374-6.

[42] Chan KH, Peiris JS, Lim W, Nicholls JM, Chiu SS. Comparison of nasopharyngeal flocked swabs and aspirates for rapid diagnosis of respiratory viruses in children. J Clin Virol 2008; 42: 65-9.

[43] Johnston SL, Siegel CS. Evaluation of direct immunofluorescence, enzyme immunoassay, centrifugation culture, and conventional culture for the detection of respiratory syncytial virus. J Clin Microbiol 1990; 28: 2394-7.

[44] Smith MC, Creutz C, Huang YT. Detection of respiratory syncytial virus in nasopharyngeal secretions by shell vial technique. J Clin Microbiol 1991; 29: 463-5.

[45] Pedneault L, Robillard L, Turgeon JP. Validation of respiratory syncytial virus enzyme immunoassay and shell vial assay results. J Clin Microbiol 1994; 32: 2861-4.

[46] Nagai K, Kamasaki H, Kuroiwa Y, Okita L, Tsutsumi H. Nosocomial outbreak of respiratory syncytial virus subgroup B variants with the 60 nucleotides-duplicated G protein gene. J Med Virol 2004; 74: 161-5.

[47] Machado AF, Sallum MA, Vilas Boas LS, Tateno AF, Machado CM. Molecular characterization of strains of respiratory syncytial virus identified in a hematopoietic stem cell transplant outpatient unit over 2 years: community or nosocomial infection? Biol Blood Marrow Transplant 2008; 14: 1348-55.

[48] Visser A, Delport S, Venter M. Molecular epidemiological analysis of a nosocomial outbreak of respiratory syncytial virus associated pneumonia in a kangaroo mother care unit in South Africa. J Med Virol 2008; 80: 724-32.

[49] Ribes JA, Seabolt JP, Overman SB. Performance characteristics of VIDAS and directigen respiratory syncytial virus (RSV) antigen detection assays and culture for the identification of RSV in respiratory specimens. J Clin Microbiol 2002; 40: 1818-20.

[50] Ohm-Smith MJ, Nassos PS, Haller BL. Evaluation of the Binax NOW, BD Directigen, and BD Directigen EZ assays for detection of respiratory syncytial virus. J Clin Microbiol 2004; 42: 2996-9.

[51] Reina J, Gonzalez Gardenas M, Ruiz de Gopegui E, et al. Prospective evaluation of a dot-blot enzyme immunoassay (Directigen RSV) for the antigenic detection of respiratory syncytial virus from nasopharyngeal aspirates of paediatric patients. Clin Microbiol Infect 2004; 10: 967-71.

[52] Gregson D, Lloyd T, Buchan S, Church D. Comparison of the RSV respi-strip with direct fluorescent-antigen detection for diagnosis of respiratory syncytial virus infection in pediatric patients. J Clin Microbiol 2005; 43: 5782-3.

[53] Jonathan N. Diagnostic utility of BINAX NOW RSV--an evaluation of the diagnostic performance of BINAX NOW RSV in comparison with cell culture and direct immunofluorescence. Ann Clin Microbiol Antimicrob 2006; 5: 13.

[54] Borek AP, Clemens SH, Gaskins VK, Aird DZ, Valsamakis A. Respiratory syncytial virus detection by Remel Xpect, Binax Now RSV, direct immunofluorescent staining, and tissue culture. J Clin Microbiol 2006; 44: 1105-7.

[55] Englund JA, Piedra PA, Jewell A, Patel K, Baxter BB, Whimbey E. Rapid diagnosis of respiratory syncytial virus infections in immunocompromised adults. J Clin Microbiol 1996; 34: $1649-53$.

[56] Hornsleth A, Friis B, Andersen P, Brenoe E. Detection of respiratory syncytial virus in nasopharyngeal secretions by ELISA: comparison with fluorescent antibody technique. J Med Virol 1982; 10: $273-81$.
[57] Falsey AR, Cunningham CK, Barker WH, et al. Respiratory syncytial virus and influenza A infections in the hospitalized elderly. J Infect Dis 1995; 172: 389-94.

[58] Casiano-Colon AE, Hulbert BB, Mayer TK, Walsh EE, Falsey AR. Lack of sensitivity of rapid antigen tests for the diagnosis of respiratory syncytial virus infection in adults. J Clin Virol 2003; 28: 169-74.

[59] Titus MO, Wright SW. Prevalence of serious bacterial infections in febrile infants with respiratory syncytial virus infection. Pediatrics 2003; 112: 282-4.

[60] Levine DA, Platt SL, Dayan PS, et al. Risk of serious bacterial infection in young febrile infants with respiratory syncytial virus infections. Pediatrics 2004; 113: 1728-34.

[61] Henrickson KJ. Advances in the laboratory diagnosis of viral respiratory disease. Pediatr Infect Dis J 2004; 23: S6-10.

[62] Grondahl B, Puppe W, Weigl J, Schmitt HJ. Comparison of the BD Directigen Flu A+B Kit and the Abbott TestPack RSV with a multiplex RT-PCR ELISA for rapid detection of influenza viruses and respiratory syncytial virus. Clin Microbiol Infect 2005; 11: 848-50.

[63] Aslanzadeh J, Zheng X, Li H, et al. Prospective evaluation of rapid antigen tests for diagnosis of respiratory syncytial virus and human metapneumovirus infections. J Clin Microbiol 2008; 46: 1682-5.

[64] Falsey AR, Formica MA, Walsh EE. Diagnosis of respiratory syncytial virus infection: comparison of reverse transcription-PCR to viral culture and serology in adults with respiratory illness. J Clin Microbiol 2002; 40: 817-20.

[65] van Elden LJ, van Loon AM, van der Beek A, et al. Applicability of a real-time quantitative PCR assay for diagnosis of respiratory syncytial virus infection in immunocompromised adults. J Clin Microbiol 2003; 41: 4378-81.

[66] Falsey AR, Formica MA, Treanor JJ, Walsh EE. Comparison of quantitative reverse transcription-PCR to viral culture for assessment of respiratory syncytial virus shedding. J Clin Microbiol 2003; 41: 4160-5.

[67] Falsey AR. Respiratory syncytial virus infection in adults. Semin Respir Crit Care Med 2007; 28: 171-81.

[68] Khanna N, Widmer AF, Decker M, et al. Respiratory syncytial virus infection in patients with hematological diseases: singlecenter study and review of the literature. Clin Infect Dis 2008; 46: 402-12.

[69] Caram LB, Chen J, Taggart EW, et al. Respiratory syncytial virus outbreak in a long-term care facility detected using reverse transcriptase polymerase chain reaction: an argument for real-time detection methods. J Am Geriatr Soc 2009; 57: 482-5.

[70] Henkel JH, Aberle SW, Kundi M, Popow-Kraupp T. Improved detection of respiratory syncytial virus in nasal aspirates by seminested RT-PCR. J Med Virol 1997; 53: 366-71.

[71] Weinberg GA, Erdman DD, Edwards KM, et al. Superiority of reverse-transcription polymerase chain reaction to conventional viral culture in the diagnosis of acute respiratory tract infections in children. J Infect Dis 2004; 189: 706-10.

[72] Henrickson KJ. Cost-effective use of rapid diagnostic techniques in the treatment and prevention of viral respiratory infections. Pediatr Ann 2005; 34: 24-31.

[73] Henrickson KJ, Hall CB. Diagnostic assays for respiratory syncytial virus disease. Pediatr Infect Dis J 2007; 26: S36-40.

[74] Miron D, Srugo I, Kra-Oz Z, et al. Sole pathogen in acute bronchiolitis: is there a role for other organisms apart from respiratory syncytial virus? Pediatr Infect Dis J; 29: e7-e10.

[75] Hall CB, Walsh EE, Long CE, Schnabel KC. Immunity to and frequency of reinfection with respiratory syncytial virus. J Infect Dis 1991; 163: 693-8.

[76] Mills Jt, Van Kirk JE, Wright PF, Chanock RM. Experimental respiratory syncytial virus infection of adults. Possible mechanisms of resistance to infection and illness. J Immunol 1971; 107: 123-30.

[77] Kuypers J, Wright N, Morrow R. Evaluation of quantitative and type-specific real-time RT-PCR assays for detection of respiratory syncytial virus in respiratory specimens from children. J Clin Virol 2004; 31: 123-9.

[78] Kuypers J, Wright N, Ferrenberg J, et al. Comparison of realtime PCR assays with fluorescent-antibody assays for diagnosis of respiratory virus infections in children. J Clin Microbiol 2006; 44: 2382-8.

[79] Liao RS, Tomalty LL, Majury A, Zoutman DE. Comparison of viral isolation and multiplex real-time reverse transcription-PCR 
for confirmation of respiratory syncytial virus and influenza virus detection by antigen immunoassays. J Clin Microbiol 2009; 47: $527-32$.

[80] Ieven M. Currently used nucleic acid amplification tests for the detection of viruses and atypicals in acute respiratory infections. $\mathbf{J}$ Clin Virol 2007; 40: 259-76.

[81] Mahony JB. Detection of respiratory viruses by molecular methods. Clin Microbiol Rev 2008; 21: 716-47.

[82] Kehl SC, Kumar S. Utilization of nucleic acid amplification assays for the detection of respiratory viruses. Clin Lab Med 2009; 29: 661-71.

[83] Freymuth F, Eugene G, Vabret A, et al. Detection of respiratory syncytial virus by reverse transcription-PCR and hybridization with a DNA enzyme immunoassay. J Clin Microbiol 1995; 33: 3352-5.

[84] Tang YW, Heimgartner PJ, Tollefson SJ, et al. A colorimetric microtiter plate PCR system detects respiratory syncytial virus in nasal aspirates and discriminates subtypes A and B. Diagn Microbiol Infect Dis 1999; 34: 333-7.

[85] Falsey AR, Erdman D, Anderson LJ, Walsh EE. Human metapneumovirus infections in young and elderly adults. J Infect Dis 2003; 187: 785-90.

[86] Syrmis MW, Whiley DM, Thomas M, et al. A sensitive, specific, and cost-effective multiplex reverse transcriptase-PCR assay for the detection of seven common respiratory viruses in respiratory samples. J Mol Diagn 2004; 6: 125-31.

[87] Moore C, Valappil M, Corden S, Westmoreland D. Enhanced clinical utility of the NucliSens EasyQ RSV A+B Assay for rapid detection of respiratory syncytial virus in clinical samples. Eur $\mathbf{J}$ Clin Microbiol Infect Dis 2006; 25: 167-74.

[88] Calvo C, Garcia-Garcia ML, Blanco C, et al. Multiple simultaneous viral infections in infants with acute respiratory tract infections in Spain. J Clin Virol 2008; 42: 268-72.

[89] Canducci F, Debiaggi M, Sampaolo M, et al. Two-year prospective study of single infections and co-infections by respiratory syncytial virus and viruses identified recently in infants with acute respiratory disease. J Med Virol 2008; 80: 716-23.

[90] Cilla G, Onate E, Perez-Yarza EG, Montes M, Vicente D, Perez-Trallero E. Viruses in community-acquired pneumonia in children aged less than 3 years old: High rate of viral coinfection. $\mathrm{J}$ Med Virol 2008; 80: 1843-9.

[91] Konig B, Konig W, Arnold R, Werchau H, Ihorst G, Forster J. Prospective study of human metapneumovirus infection in children less than 3 years of age. J Clin Microbiol 2004; 42: 4632-5.

[92] Semple MG, Cowell A, Dove W, et al. Dual infection of infants by human metapneumovirus and human respiratory syncytial virus is strongly associated with severe bronchiolitis. J Infect Dis 2005; 191: 382-6.

[93] Richard N, Komurian-Pradel F, Javouhey E, et al. The impact of dual viral infection in infants admitted to a pediatric intensive care unit associated with severe bronchiolitis. Pediatr Infect Dis J 2008; 27: 213-7.

[94] Buckingham SC, Bush AJ, Devincenzo JP. Nasal quantity of respiratory syncytical virus correlates with disease severity in hospitalized infants. Pediatr Infect Dis J 2000; 19: 113-7.

[95] DeVincenzo JP, El Saleeby CM, Bush AJ. Respiratory syncytial virus load predicts disease severity in previously healthy infants. J Infect Dis 2005; 191: 1861-8.

[96] Murphy BR, Alling DW, Snyder MH, et al. Effect of age and preexisting antibody on serum antibody response of infants and children to the $\mathrm{F}$ and $\mathrm{G}$ glycoproteins during respiratory syncytial virus infection. J Clin Microbiol 1986; 24: 894-8.

[97] Popow-Kraupp T, Lakits E, Kellner G, Kunz C. Immunoglobulinclass-specific immune response to respiratory syncytial virus structural proteins in infants, children, and adults. J Med Virol 1989; 27: 215-23.

[98] Johnson KM, Chanock RM, Rifkind D, Kravetz HM, Knight V. Respiratory syncytial virus. IV: correlation of virus shedding, serologic response, and illness in adult volunteers. JAMA 1961; 176: 663-7.

[99] Anderson LJ, Hierholzer JC, Bingham PG, Stone YO. Microneutralization test for respiratory syncytial virus based on an enzyme immunoassay. J Clin Microbiol 1985; 22: 1050-2.

[100] Wu W, Tang YW. Emerging molecular assays for detection and characterization of respiratory viruses. Clin Lab Med 2009; 29: 673-93.

(C) Popow-Kraupp and Aberle; Licensee Bentham Open.

This is an open access article licensed under the terms of the Creative Commons Attribution Non-Commercial License (http://creativecommons.org/licenses/ by-nc/3.0/) which permits unrestricted, non-commercial use, distribution and reproduction in any medium, provided the work is properly cited. 